\title{
An Overview on Major Design Constraints, Impact and Challenges for a Conventional Wastewater Treatment Design
}

\author{
Saidur R Chowdhury ${ }^{1 *}$, Feras Alhelal ${ }^{2}$, Mohammad Alahmadi ${ }^{3}$, Naif Alqahtani ${ }^{2}$, Abdullah \\ Alkhaldi ${ }^{2}$, Andi Asiz ${ }^{3}$
}

\begin{abstract}
${ }^{1}$ Assistant Professor, Civil Engineering Department, Prince Mohammad Bin Fahd University (PMU), Al khobar, Saudi Arabia ${ }^{2}$ Saudi Consolidated Engineering Company, Khatibalami, Khobar, King Faisal Road. KSA ${ }^{3}$ Civil Engineering Department, Prince Mohammad Bin Fahd University (PMU), Al khobar, Saudi Arabia
\end{abstract}

Received: 08/07/2020

Accepted: 04/09/2020

Published: 20/12/2020

\begin{abstract}
The conventional wastewater (WW) treatment plant includes physical, chemical, and biological treatment processes that can protect the receiving water bodies from water pollution. The common design constraints, challenges as well as environmental impact would make the wastewater treatment plant's (WWTP) construction and operation more complex and demanding tasks. Major project constraints for WW plant design are economics, accessibility, fulfilling technical requirements, institutional set-up, health and environment, personnel capacity, and political commitment etc. Design methodology adopted in the current study included project location, unit selections, the design capacity, design period as well as proximity to the population and layout plan. The present manuscript discussed briefly about effluent quality requirements, design issues, environmental impacts, details, and safety concerns. It also highlighted the necessary flexibility to carry out the treatment satisfactorily within the desired range of influent WW characteristics and flows. In the present study, every step of the design was verified with Environmental Regulations and suggested to overcome all constraints while designing WWTPs so that standard operational code for the specific region could be implemented to achieve the best treatment performance. The results obtained from analytical calculation were optimized to achieve the best design parameters for field application. The optimized values also reduce the construction and operation cost during the field application.
\end{abstract}

Keywords: Wastewater (WW), Challenges, Constraints, Design, Impact, Treatment, Plant

\section{Introduction}

Wastewater (WW) treatment plant is very important as any other necessary facility for constructing a sustainable city. Domestic wastewater treatment consists of various units to remove different types of contaminants from WW (1-3). It includes physical, chemical, and biological treatment processes that can protect the receiving water bodies from water pollution, make recycled water as well as reduce the volume of sewage water and sludge (4). Environmental benefits from WW include safer and more stable healthy aquatic ecosystems and reduce amount of wastewater released into the environment without any treatment (5). Any wastewater treatment provides an opportunity for sustainable solution to some aspects of the water scarcity problem (6). The proper management of wastewater develops the sustainable and healthy environment (5). The common design constraints, challenges as well as environmental impact would make the WW treatment plant's construction and operation more complex and demanding tasks. WW treatment contains a series of steps that can have increasing effectiveness and complexity depending on the resources' availabilities (7). The conventional steps include primary, secondary to tertiary treatment (1). Primary treatment considers as the first step of WW treatment. Many advanced WWTPs located in the developed countries started with primary treatment and then equipped with other treatment units as increasing wastewater loads and the requirement to produce clean water prior to final disposal into receiving bodies (7). The treatment also increases the production of treated water for agriculture and other developments. Primary treatment is used to reduce suspended and floating solids from raw WW. This level can be defined as mechanical or physical treatment, although chemicals are often applied to complete the sedimentation process (8). Primary treatment can reduce the biochemical oxygen demand $\left(\mathrm{BOD}_{5}\right)$ and chemical oxygen demand $(\mathrm{COD})$ of the incoming wastewater by $25-50 \%$ (8-9). During primary treatment, the total suspended solids are removed by approximately $50-70 \%$ as well as $65 \%$ removal could be achieved for oil and grease (9). Secondary to tertiary treatment applies to purify wastewater more and can also act as a resource recovery unit (7).

*Corresponding author: Saidur R Chowdhury, Civil Engineering Department, Prince Mohammad Bin Fahd University (PMU), Al-khobar, Saudi Arabia. E-mail: schowdhury1@pmu.edu.sa 
The production and maintenance cost of treated water exceeds that of potable water in many regions of the world where sources of fresh water supply are plentiful. However, introduction to innovative technology in the water industry, the reclaimed water is usually sold to citizen at a cheaper rate to encourage it's use (7). Ouda (7) further reported that fresh water supplies to the community would be inadequate due to increased population demands, or unplanned urbanization, and reducing clean water sources. In addition, using reclaimed water for non-potable uses save potable water for drinking, since less potable water is used for non-potable uses such as irrigation. Every human being uses the water in different way such as domestic, agriculture, and industrial or even for drinking. In the present study, design constraints, environmental impacts, costs and few challenges were highlighted to develop any conventional treatment plant in any newly developed cities. The outcome of the present study was extracted from the student capstone project in the civil engineering department at Prince Mohammad bin Fahd University (PMU) in Saudi Arabia. The study explored the processes to complete any conceptual treatment design within limited resources. In the present study, a large area in Al Firdous District under Jubail Industrial City in Eastern Province was selected to develop a sustainable new housing district. This new district includes houses, commercial complexes, multi-storey building, and gas stations. It is expected that in addition to the current volume of wastewater, a significant amount of wastewater would be generated from the area in the near future. If this wastewater would be discharged into the environment without treatment, it could be a severe threat to the public health and hazard to the environment. Thus, the proposed wastewater treatment plant within the new districts can help to reduce the pressure on the existing wastewater treatment plant (WWTP) in Jubail Industrial City in Kingdom of Saudi Arabia (KSA).

The present study aimed to design a wastewater treatment plant to serve the community. The scope and objectives of the study were to evaluate major design constraints, impact and challenges while designing any conventional WW treatment plants. The manuscript also included the required consideration for plant construction site, the degree of effluent quality, design issues and details, outfalls, important facilities and common safety issues. The study also calculated volume of WW to be generated during the design period of 25 years; to develop the conceptualized design for the primary and secondary wastewater treatment units (based on the estimated wastewater); to assess the environmental impact of the proposed wastewater plant. The present study also verified major design requirement and consideration for successful WW plant operations. Till to date, very few studies have investigated constraints, impact and challenges for a conventional WW treatment plant design. This was one of the studies that focused on the basic information necessary to overcome the design constraint, sustainability and key challenges for constructing conventional WW treatment plant within newly developed cities under different environmental conditions.

\section{Study Methodology}

The methodology used in the study included: by reviewing and verifying literatures on WWTP design, recent site related WW document studies, site history, evaluating feasibility of site condition through field visits, verification of existing sources of
WW, applying standard practices for the necessary design parameters and optimizing design parameters based on applicable constraints and regulations. A proposed WWTP project intended to be located in Al Firdous District of Jubail Industrial City was used as the main vehicle for analyzing and synthesizing design information, process, and optimization. In the study, all analytical calculations for different design parameters were optimized by MS Excel Solver for verification and Justification.

Environmental Impact Assessment (EIA) was evaluated by field visits and document study. The results of EIA for the proposed project were verified and contrasted with the recent design practices. Important information about the project site and existing environmental condition was discussed with the Local City Corporation and stakeholder to ensure its feasibility. All observations and design constraints were identified, compared, verified as well as provided justification for solution by the investigators. Design steps were evaluated based on applicable theories, expert opinion, site condition, and optimum standard values. At the end, all potential challenges were summarized in this study and their possible solutions were discussed. The manuscripts also listed some important considerations to successfully complete any WWTP design that could fit with site condition for a newly developed plant.

\section{WW Project Constraints and operational code}

Sustainable development provides a good standard of living in any society. It can facilitate important solutions to the financial, environmental, and societal challenges without causing a hazard to human and environmental issues. Environmental protection and conservation of natural water body consider design requirement and design consideration significantly while any sustainable development in environmental sector takes place. Water pollution from wastewater discharges may vary depending on their types, sources and strength. These wastewaters entered into the natural water body through various channel can cause a great concern to community. The conventional WW treatment can reduce this problem. Prior to constructing WW plant, numerous constraints need to be checked for sustainability. Any design constraint for WW project means the list of problems that are counted to overcome prior to the final design approval in case of successful construction and plant operation. Major project constraints for wastewater plant design (WWTP) are economics, accessibility, health and environment, prevailing wind direction, suitability of hydrogeological condition, fulfilling technical facilities, institutional set-up and personnel capacity and policy/political commitment etc.

Another major constraint for wastewater treatment plant is enforcement of standards' monitoring. The design capacity for wastewater plant should be such that the treated effluent would continuously meet accepted quality criteria that can reduce any risk. WWT related risk occurs due to the failure to meet established standards at source (i.e. WW treatment outflow); not complying standard operation procedure (SOPs); lack of qualified employees to monitor treatment facilities; ineffective monitoring of WW reuse system; absence of skilled personnel; lack of proper monitoring equipment; and expensive operation and monitoring costs (Ministry of the Environment 2008) (10).

An area selected for treatment plant also requires some important consideration such as distance from wastewater source and final discharge point for treated effluent, landscape as well as 
neighbourhood community. Local temperature, rain, humidity as well as climate also affect different treatment unit performance. For example, bacterial growth in aeration tank during high temperature as well as excess flows due to rainwater could affect the processes and removal capacity. Readily available materials and chemicals should be considered during the plant's construction and operation. These constraints could affect the project cost. Lack of sufficient skilled personnel also affects the equipment handling during plant operation. Those common constraints should be checked prior to finalize the treatment plant projects. After constraint study, another important factor such as operation/design code followed by environmental rules and regulation in any country should be verified. In the present study, every step of the design was verified with Royal Commission Environmental Regulations (2004) as well as Presidency of Meteorology and Environment Regulations and rules in KSA (2001) (11-12). The conceptualized discharge water quality was established as per performance standards for discharge according to KSA environmental regulation. Figure 1 shows the major constraints for a wastewater treatment plant design. All constraints should be overcome so that standard operational code for the specific region can be implemented to achieve the best treatment performance.

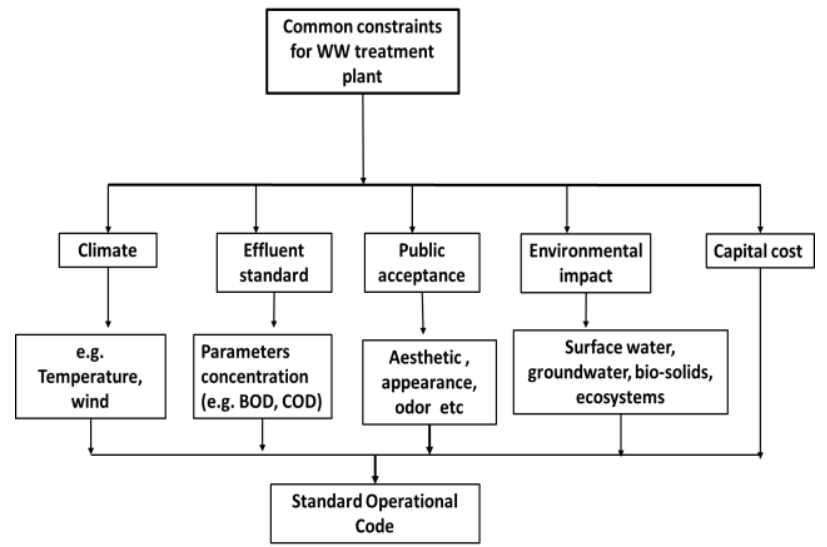

Figure 1: The flow chart of major constraints for a WW treatment plant design

\section{Environmental Impact Assessment (EIA) and WW Project}

EIA study is an essential part for any sustainable WW project implementation. It can help to decide the best project location for the construction of treatment plants and also protect individuals, society and environment from any bad effect due to the construction of WW treatment plant. The investigation also identifies adequate safety measures to be introduced to ensure public safety and local environment, which might arise due to any emergency or unexpected situation (13). They reported that it would also evaluate the proper monitoring and operational condition to be required for wastewater treatment plant.

In the present study, EIA was divided into two portions. First portion was documents or historical information review and second portion included site visit and field investigation (FI). In order to carry out the EIA of proposed wastewater treatment plant, a baseline study was conducted for project location, neighbourhood or site surrounding environmental study, population growth, climate, effluent discharge, operational, and ecology. Parameters of importance can be defined from this EIA study as well as standards for discharge can be selected to establish permissible limits of contaminants in WW effluents being treated at the plant (14). Appropriate mitigation measures were evaluated and recommended to be incorporated into the intended plant. Table 1 represents the primary list of items to be verified for the purpose of environmental impact assessment prior to plant design. An example was provided in Table 1 that showed important items of preliminary EIA study for Al- Firdous District WWTP under Jubail Industrial City in Eastern Province in KSA (prior to WWTP design). The status of important environmental parameters (for the development of treatment plant) at the proposed site was checked and verified.

In the first stage of EIA, the historical documents about neighbourhood, their life style and standard, site information, any accidental spillage or event as well as population growth etc. were checked for the proposed location. Prior to finalizing the design, different environmental parameters such as prevailing wind direction, land, location and accessibility of the plant site, hydrogeologic condition, soil and topography, discharged point, as well as sludge management were checked and compared with Saudi Environmental Regulation standards (2001) (12). The second portion of the study was field investigation (FI). If the result from portion one study fails to fulfil the requirement as per standard, FI would be deemed necessary to confirm the findings obtained from the portion one study. FI generally includes soil, groundwater collection and field or laboratory investigation as well as hydrogeological parameters' identification, such as wells or groundwater flow.

\section{Important Steps for WWTP design}

Design methodology adopted in the current study included project location, unit selections, capacity, the design capacity, design period, environmental assessment (e.g. wind direction) as well as proximity to the population and layout plan.

\subsection{Location of treatment plant}

A new WW treatment plant site or an expansion of an existing WW treatment plant must be evaluated by the Professional Engineers (Ministry of the Environment 2008) (10). The treatment plant should be situated close to the point of disposal. An important care should be considered while selecting the site. The plant site should be located on the downstream portion of the city and also sufficiently away from water intake works, drinking water sources, and groundwater wells. If the final disposal of treated effluent would be on natural water bodies or abandoned ponds/low land, the plant must be located near to the disposal point so that the site can receive the treated sewage directly under gravitational forces. The plant site should not be far away from the town so that the length of the sewer line could be less. 
Table 1: Selected items to be verified for the preliminary environmental impact assessment (EIA) prior to the design (an example for AlFirdous District WWTP under Jubail Industrial City in Eastern Province in KSA)

\begin{tabular}{|c|c|c|c|}
\hline Selected items for EIA & Satisfied & $\begin{array}{l}\text { Not checked/ } \\
\text { not satisfied }\end{array}$ & Remarks/Comments \\
\hline $\begin{array}{l}\text { Historical document studies around the } \\
\text { project site }\end{array}$ & $\sqrt{ }$ & & Checked previous land uses, living standards, population etc. \\
\hline Proposed land area for WWTP facilities & $\sqrt{ }$ & & $\begin{array}{l}\text { The subject site is vacant and plain land. Enough space available for } \\
\text { future expansion and sludge disposal/utilization close to the site }\end{array}$ \\
\hline $\begin{array}{l}\text { Neighborhood or site surrounding } \\
\text { environment study for project site } \\
\text { evaluation }\end{array}$ & $\sqrt{ }$ & & $\begin{array}{l}\text { Nothing (e.g. natural significance area, parks or institute) observed } \\
\text { within } 250 \mathrm{~m} \text { of the proposed location. The study protects human, all } \\
\text { living being and their surrounding such as air and soil from } \\
\text { environmental hazards. }\end{array}$ \\
\hline $\begin{array}{l}\text { Capacity of the treatment plant to be } \\
\text { handled }\end{array}$ & $\sqrt{ }$ & & $\begin{array}{l}\text { Wastewater or toxic substances could be collected (within the plant } \\
\text { capacity) without deleterious effects and without destruction to aquatic } \\
\text { environment or humans who consume/use the water. }\end{array}$ \\
\hline $\begin{array}{l}\text { WW sources and physical condition (e.g. } \\
\text { temperature, flow, size, types of waste } \\
\text { etc.) }\end{array}$ & $\sqrt{ }$ & & Sources as well as quantity of wastewater checked \\
\hline $\begin{array}{l}\text { Location and accessibility of the project } \\
\text { site }\end{array}$ & $\sqrt{ }$ & & Easily accessible to the plant. Few kilometers from the WW sources. \\
\hline $\begin{array}{l}\text { Population Centers } \\
\text { from project site }\end{array}$ & $\sqrt{ }$ & & $\begin{array}{l}\text { Population centers are an advantage for WWTPs from the point of } \\
\text { view of ease of supply planning. }\end{array}$ \\
\hline $\begin{array}{l}\text { Prevailing wind direction of the project } \\
\text { site }\end{array}$ & $\sqrt{ }$ & & Odor (generation from wastewater plant) towards the sea \\
\hline Soil and topography of the project site & $\sqrt{ }$ & & $\begin{array}{l}\text { Shrubs need to be cleared at the project location during the excavation } \\
\text { work }\end{array}$ \\
\hline $\begin{array}{l}\text { Hydro-geologic condition of the project } \\
\text { site }\end{array}$ & $\sqrt{ }$ & & $\begin{array}{l}\text { No wells on or near the site. Groundwater depth approximately } 2 \mathrm{~m} \\
\text { below the grade. Cautious required to prevent GW contamination }\end{array}$ \\
\hline $\begin{array}{l}\text { Waste management and constraints of the } \\
\text { project site }\end{array}$ & & $\sqrt{ }$ & $\begin{array}{l}\text { Sludge collected from plant to be used for different engineering } \\
\text { purposes }\end{array}$ \\
\hline $\begin{array}{l}\text { Soil types or condition for any facility } \\
\text { development in proposed WWTP }\end{array}$ & $\sqrt{ }$ & & Mostly sand \\
\hline Ambient air parameter of the project site & & $\sqrt{ }$ & Not checked \\
\hline Soil and groundwater testing & $\sqrt{ }$ & & $\begin{array}{l}\text { All laboratory investigations were conducted by third party. No toxic } \\
\text { substance detected. }\end{array}$ \\
\hline Discharged point & $\sqrt{ }$ & & Final disposal towards Sea \\
\hline Performance standards for discharge & $\sqrt{ }$ & & $\begin{array}{l}\text { Checked with KSA } \\
\text { Environmental Regulation }\end{array}$ \\
\hline
\end{tabular}

Notation: $\sqrt{ }=$ Checked and Satisfied

On the other hand, the plant site should not be too close to the city, that it can create problems in the expansion of city and can contaminate the neighbourhood or general atmosphere by smell, fly and nuisance (15-17). The building orientation and location can be utilized to reduce the effects of odours. Susceptibility of site to flooding, soil conditions, and suitability of subject site with respect to access to receiving body of water should be investigated by Professional Engineers prior to finalizing the WWTPs location (Ministry of the Environment. 2008) (10). In the selected location of WWTPs, the design engineers should consider a plant layout where the different processing units would be constructed or arranged in a logical progression. The plant layouts are facilitated to offer for convenience of operation and ease of flow splitting for different treatment units. In addition, the selected site has enough space to accommodate future plant expansion so that any additional processes can be installed to recover the treatment quality.

\subsection{Design period}

The design period should be chosen based on useful life, wear and tear, expected population growth and infrastructural developments, feasibility for addition or expansion, financial constraints and interest rate $(1,18-19)$

The treatment plant is commonly designed and constructed that can meet the demand for plant operation over 20 to 25 years' period $(8,10)$. The time lag between the design and completion of plant construction should not be more than 2-3 years. A WWTP also involves installing of underground sewer pipes that can carry all WW as well as construction of costly treatment units. The units which cannot be replaced or increased in their capacities easily or conveniently at a later date should be considered always while designing any plant. The future expansions of the city and consequent growth in the WW quantity should be forecasted (within design period) in order to avoid such complications. All units can serve the community satisfactorily for a reasonable year. A care should be considered that the plant should not be under loaded in the initial stages, particularly the sedimentation tank. The design engineer should set the ultimate design period to be 20 to 25 years and to that extent sufficient accommodation should be accommodated for all the units necessary to fulfil the need of forecasted population. 


\subsection{Layout Plan}

Proper wastewater layout plan must be completed before design flow establishes. A site for WWTP would be considered on the basis of evaluation of the entire drainage area, the topographic map, subsurface conditions and natural grades that could facilitate the necessary services at a minimum cost (Ministry of the Environment, 2008) (10). The preliminary layout of wastewater is most commonly prepared from the topographic map (18). In general, wastewater sewers are located on streets or on available right of way and are sloped in the same direction as the slope of the natural ground surface. Preliminary layout and routing of wastewater flow can be done by considering several feasible alternatives. In each alternative, factors (such as total length of wastewater treatment, cost of construction, operation and maintenance) also consider to build a cost effective wastewater system. Finally, these flow channel layout plans are revised after several field visits and investigation to the location. On the other hand, all building structures proposed in the layout of the plant should facilitate adequate allowances for the future linear expansions of the various treatment stages and process for different unit. The designer orients the plant so that the best advantage can be provided from the prevailing wind and climate conditions. The building orientation can be set to decrease effects of odours, energy usage (heating) and other operational problems. To avoid the necessity for major pipelines or conduits to convey $\mathrm{WW}$, sludges from one units to other, the various processing units are set in a logical progression so that the arrangement of plant layout can provide for convenience of operation and ease of flow splitting for proposed and future treatment units. Moreover, designer should keep some space for the provision of future treatment plant expansions if necessary. Figure 2 shows the major design consideration for WWTP project.

\section{Degree of Treatment and Basic Design}

The degree of treatment would be based on the influent characteristic and the required effluent quality. Final sludge disposal options or resource recovery options can dictate the choice of treatment processes as well as the effluent quality. The available land area, soil or geo-hydrological conditions, treated WW during periods of the year (where receiving streams experience insufficient flows) and downstream recreational water uses also have direct indirect influences in case of the treatment method selection (Ministry of the Environment, 2008) (10). The technical supports such as operator skills, mechanical performance, future loads such as hauled septage as well as leachate handling, operation and maintenance (O\&M) costs are one of the considerations to select the degree of treatment. Before deciding upon the WW treatment processes, the designer should assess the alternative options available to conduct the required level of treatment (in terms of treatment capability, overall capital and operational costs). If the effluent is discharged into the natural water, it should comply with the national discharge quality requirements. If treated water used for land irrigation, the plant effluent must also satisfy the health regulation governing the types of crops that are irrigated. The treated effluent can be used for recreational lakes, agriculture, industrial and municipal purposes. Thus, requirement for WW discharge based on uses may dictate the effluent quality and the degree of treatment (18). Figure 3 shows the conventional domestic wastewater treatment units for the conventional project.

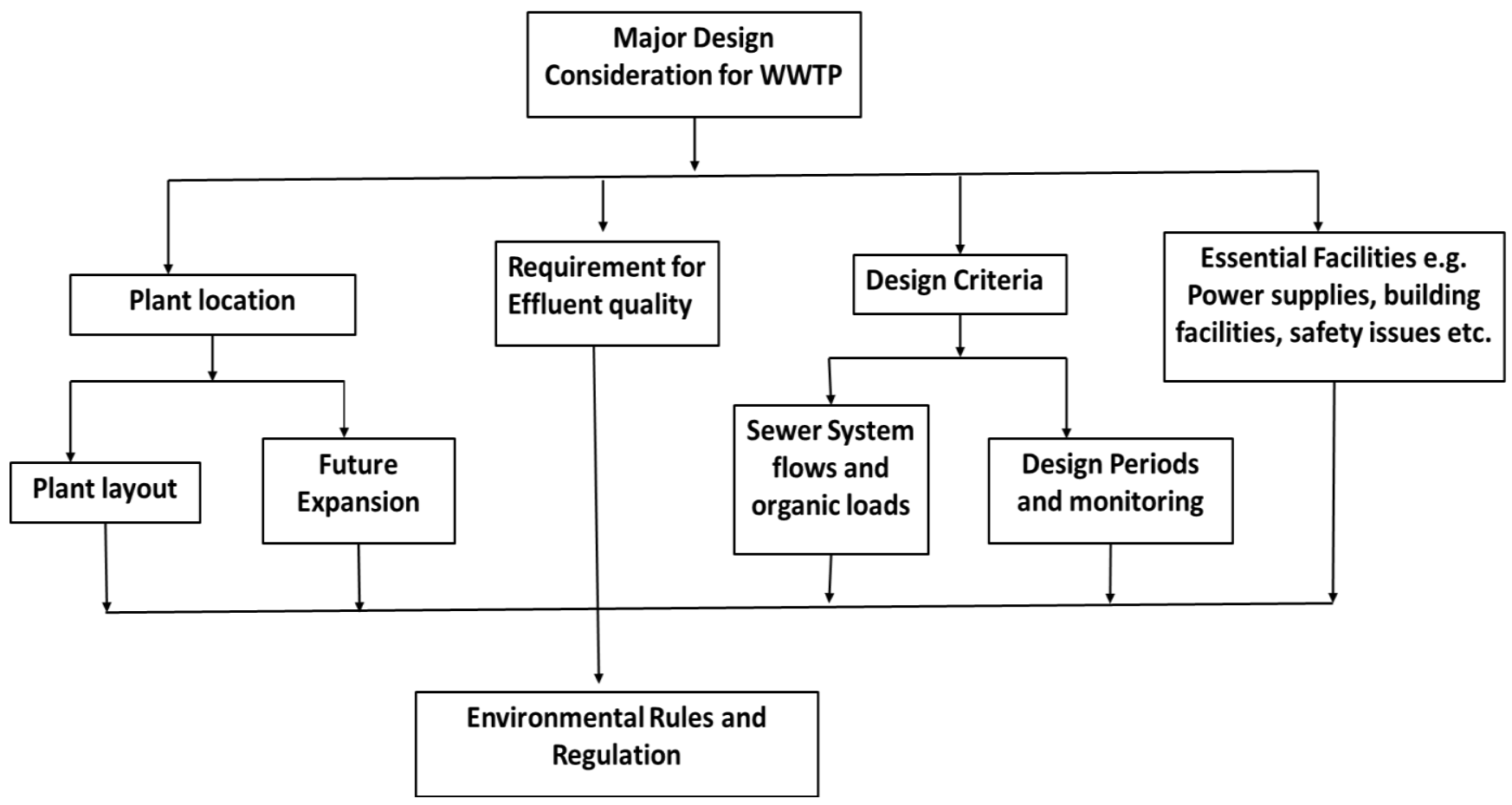

Figure 2: The major design consideration for WWTP project 

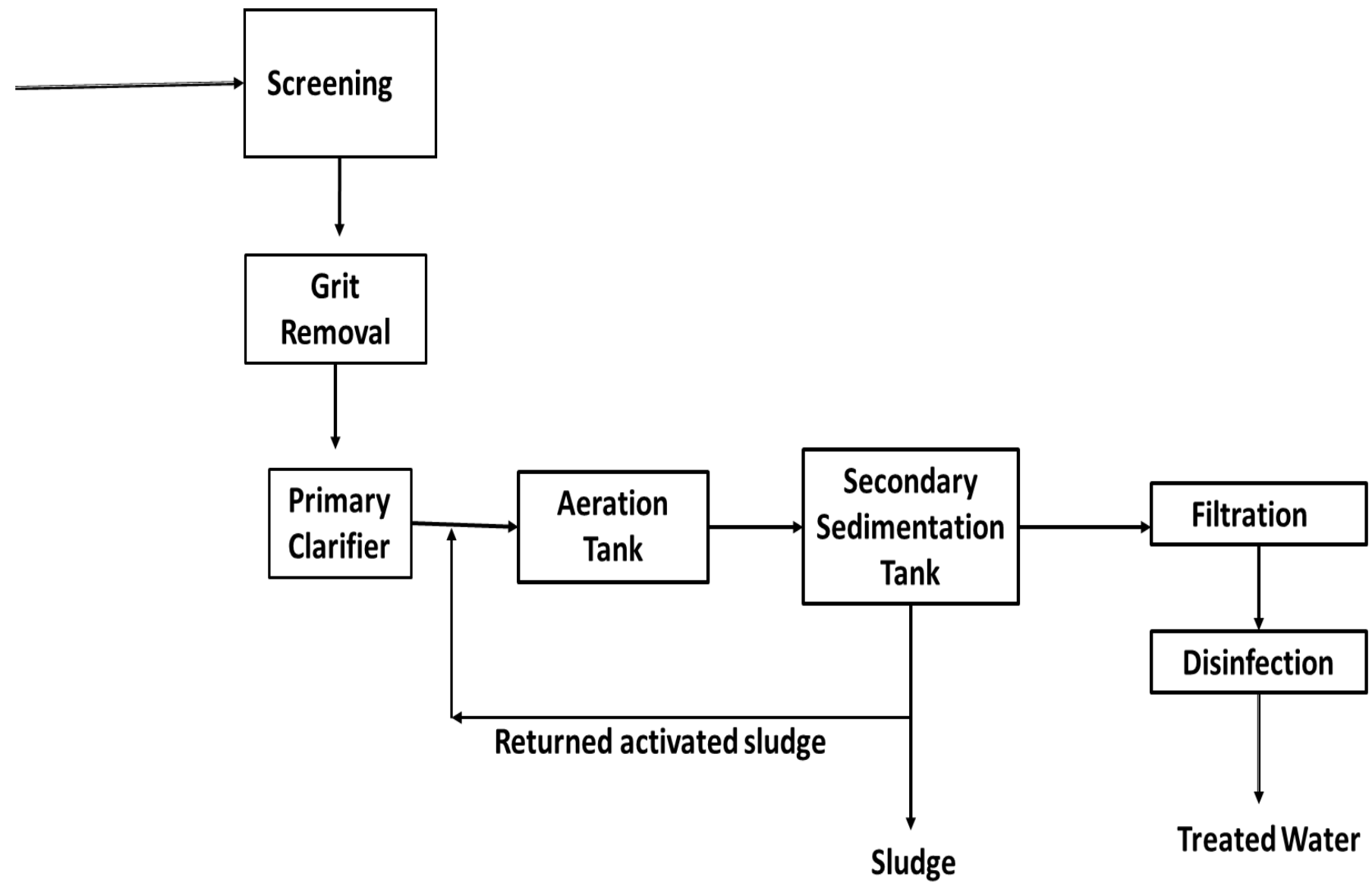

Figure 3: The proposed domestic wastewater treatment units

The conventional WWTP design would focus on the maximum removal of Biochemical Oxygen Demand (BOD), Total Solid (TS) and Suspended Solids (SS), Settleable Solids, Total Kjeldahl nitrogen (TKN) and Total Phosphorus (TP). In the present study, the treatment plant was proposed to treat domestic or municipal WW. WW would require the primary treatment to remove large objects, grits and sludge (as shown in Fig 3). Then, the WW would be conveyed to the secondary WWTPs for further treatment. The medium strength of wastewater was considered as influent wastewater for different treatment units while designing the WWTP project.

The study assessed the performance of suspended solid aerobic treatment unit for municipal wastewater generated from almost 83000 population in Al Jubail residential area. The design also considered assessing the site condition, biomass calculation, Food and micro-organism $(\mathrm{F} / \mathrm{M})$ ratio, amount of recycled activated sludge, TSS, VSS, COD, BOD removal efficiency as well as physical and process design of the proposed wastewater. The study also evaluated important design parameters (e.g. environmental and Hydraulic) for screening, grit removal, primary/secondary treatment units and also verified with Royal Commission Environmental Regulations as well as Presidency of Meteorology and Environment Regulations and rules in KSA. Table 2 listed few basic equations necessary for activated sludge tank design proposed in the study.
The notations of all parameters for activated sludge tank were included in Column 2 under the Table 2. All important equations used for calculating design parameters were presented in the, Table 2 Column 1. At the beginning, the predicted populations were calculated using the basic growth equation. Then, receiving water chamber was designed. This tank structure at the entrance of the treatment plant to receive the wastewater approaching through a wastewater system and main pipe would be connected to the first unit tank. Three Bar screens such as two mechanicals with 90 degrees and one manual with 45 degrees were proposed to trap and remove the floating materials such as cans, papers, tree leaves, timber pieces etc. In the design, grit chamber would be proposed to be placed after the screening to remove the inorganic particles. A settling tank called primary sedimentation tank was designed to remove the organic solids. In this study, aeration tank was designed for secondary treatment facilities. The amount of activated sludge from secondary sedimentation tank was calculated and to be used for the aeration tank. Table 2 shows all important equations used to calculate the design parameters for the aeration tank design. The overall successful design could be achieved by accomplishing environmental system design, hydraulic flow design as well as physical and structural design of the plants (20). 
Table 2: Few basic equations necessary for activated sludge tank design (8)

\begin{tabular}{|c|c|c|}
\hline Equations & Parameters & Descriptions \\
\hline $\mathrm{Q}=\mathrm{P} * \mathrm{Q}^{\prime} / 1000$ & $\begin{array}{l}\mathrm{Q}=\text { Maximum WW flow rate; } \mathrm{P}=\text { future population; } \\
\mathrm{Q}=\text { = Wastewater produced (Liter per capita) }\end{array}$ & $\begin{array}{l}\text { Estimation of maximum } \\
\text { designed flow rate }\end{array}$ \\
\hline$\theta=\frac{V}{Q}$ & $\begin{array}{l}\theta=\text { hydraulic retention time }(\text { days }) \\
\mathrm{V}=\text { aerated tank volume, } \mathrm{V}\left(\mathrm{m}^{3}\right)\end{array}$ & From flow rate \\
\hline$V=\frac{Y Q \theta c(S o-S)}{X(1+K d \theta c)}$ & $\begin{array}{l}\mathrm{Y}=\text { Yield coefficient or bacteria growth rate; } \theta c= \\
\text { sludge age, days } ; \text { So }=\text { Concentration of dissolved } \\
\text { pollutants such as BOD, } \mathrm{mg} / \mathrm{L} ; \mathrm{S}=\mathrm{Concentration} \text { of } \\
\text { dissolved pollutant in aerated tank and the effluent, } \\
\mathrm{mg} / \mathrm{L} ; \mathrm{k}_{\mathrm{d}}=\text { Decay rate of the bacteria; } \mathrm{X}=\text { The } \\
\text { mixed liquor suspended solid concentration MLSS }\end{array}$ & $\begin{array}{l}\text { Estimation of aerated tank } \\
\text { volume, } \mathrm{V}\left(\mathrm{m}^{3}\right)\end{array}$ \\
\hline$\theta c=\frac{Y X}{Q w X r+(Q-Q w) X e}$ & $\begin{array}{l}\mathrm{Q}_{\mathrm{w}}=\text { Waste sludge flow rate } \mathrm{m}^{3} / \text { day; } \mathrm{X}_{\mathrm{r}}= \\
\text { Concentration of recycled activated sludge; } \mathrm{X}_{\mathrm{e}}= \\
\text { Effluent suspended solid concentration, mg/L; }\end{array}$ & Estimation of sludge age \\
\hline$Q r=Q \frac{X}{X r-X}$ & $\mathrm{Qr}=$ Return sludge flow rate, $\mathrm{m}^{3} /$ day; & \\
\hline$\frac{F}{M}=\frac{Q S o}{V X}$ & $\begin{array}{l}\mathrm{F}=\text { Food ( e.g. amount of COD or BOD } \\
\text { concentration, } \mathrm{mg} / \mathrm{L}) ; \mathrm{M}=\mathrm{Micro}-\text { organisms ( e.g. } \\
\text { concentration of VSS, mg/L) }\end{array}$ & $\begin{array}{l}\text { Food and micro- } \\
\text { organisms ratio for } \\
\text { optimum operation }\end{array}$ \\
\hline$\frac{d x}{d t}=\frac{V X}{\theta c}$ & $\mathrm{dx}=$ the change of VSS $; \mathrm{dt}=$ the change of time & $\begin{array}{l}\text { The rate of sludge } \\
\text { production }\end{array}$ \\
\hline$U=\frac{\mu \mathrm{m} \mathrm{SX}}{\mathrm{Y}(\mathrm{Ks}+\mathrm{S})}$ & $\begin{array}{l}\mathrm{U}=\text { Substrate utilization rate }(\mathrm{e} . \mathrm{g} . \text { food consumption } \\
\text { by micro-organisms); Ks = half velocity constants; } \\
\mu_{\mathrm{m}}=\text { maximum growth rate constant, } \mathrm{d}^{-1}\end{array}$ & $\begin{array}{l}\text { Total substrate } \\
\text { consumption calculated } \\
\text { by multiplying tank }(\mathrm{v}) \\
\text { volume, } \mathrm{m}^{3} \text {. }\end{array}$ \\
\hline
\end{tabular}

\section{Design Optimization}

After the analytical calculation, the calculated values need to be justified or optimized so that the accuracy of the design parameters would be fitted well with the environmental processes as well as construction operation during the field application. Design constraints also control the parameter selection. In this project, MS excel solver was used to solve and optimize the design parameters. The solver results act as criteria or standard. Solver can work with a group of compartments, called decision variables or simply variable cells that are used in computing the formulas in the certain scope and constraint cells. It can adjust the values in the decision variable cells to fulfill the limits on constraint cells and calculate the results the design engineer wants for the objective cell.

In this project, some parameters used were constant and some were variable while operating the excel solver to evaluate the targeted parameters. The solver optimized the results within the range. Those calculations were based on the width, depth, area, slope, friction with slope and flow rate. Table 3 shows an example of design of Bar Screen and the channel flow using analytical and solver solutions that was used while designing Al Firdous District WWTP under Jubail Industrial City in Eastern Province in KSA.

Similarly, all other parameters calculated by analytical methods for other units (e.g. sedimentation tanks, aeration tank, filtration or coagulation) were verified with the solver results so that the results were optimized to achieve the best design parameters for field application. The optimized results also reduce the construction and operation cost as well as overcome all design constraints identified prior to the design approval. The optimized parameters fit well with filed application and save construction time.

\section{A Conventional Challenges in WW plant}

The common challenge in WW industry is to remove contaminants as per requirement so that the desire goals can be achieved. The application of treated WW can control the treatment mechanisms as well as the effluent quality. For example, WW usage in agricultural activities should be always treated at the level that always conforms the standard limit set for agricultural water quality. If treated water is discharged into natural water bodies, the level of treatment should be able to control any detrimental effect generated from the disposal in aquatic environment. Thus, the primary challenge in WW industry is to maintain the quality of WW. The selected treatment needs to meet with current regulatory standards as well as reduce the environmental impact on the receiving water body (21). Another challenge in the WW treatment project is construction and operating costs. It should be optimized. Cost estimation for wastewater treatment plant is one of the major tasks in any project. 
Table 3: Design of Bar Screen and the channel flow using analytical and solver solutions (for Al- Firdous District WWTP under Jubail Industrial City in Eastern Province in KSA)

\begin{tabular}{|c|c|c|c|c|}
\hline Input data & \multicolumn{2}{|l|}{ Solver } & Hand calculation & $\begin{array}{l}\text { Optimum } \\
\text { Values } \\
\text { (Davis, 2011) }\end{array}$ \\
\hline Coefficient of roughness $(\mathrm{n})$ & \multicolumn{2}{|l|}{0.012} & 0.012 & - \\
\hline Discharge, $\mathrm{Q}\left(\mathrm{m}^{3} / \mathrm{s}\right)$ & \multicolumn{2}{|l|}{0.456} & 0.456 & - \\
\hline Slope of energy grade line, $\mathrm{S}(\mathrm{m} / \mathrm{m})$ & \multicolumn{2}{|l|}{0.0001} & 0.0001 & - \\
\hline Width, m & \multicolumn{2}{|l|}{1} & 1 & \\
\hline Depth, $\mathrm{m}$ & \multicolumn{2}{|l|}{1} & 1 & \\
\hline \multicolumn{5}{|l|}{ Calculated velocity } \\
\hline Adjusted Area $\left(\mathrm{m}^{2}\right)$ & $\mathbf{A}=$ & 1.04 & & - \\
\hline Perimeter, $\mathrm{m}$ & $\mathrm{P}=$ & 2.89 & 3 & - \\
\hline \multirow[t]{3}{*}{ Hydraulic radius, $m$} & $\mathrm{R}=$ & 0.36 & 0.33 & - \\
\hline & $R^{\wedge} 2 / 3=$ & 0.506 & 0.478 & - \\
\hline & $S^{\wedge} 0.5=$ & 0.01 & 0.01 & - \\
\hline Velocity of channel flow, $\mathrm{m} / \mathrm{s}$ & $\mathrm{v}$ & 0.43 & 0.39 & - \\
\hline Adjusted flow rate, $\left(\mathrm{m}^{3} / \mathrm{s}\right)$ & Q & 0.45 & & - \\
\hline Cross sectional area of flow, $\mathrm{m}^{2}$ & $\mathrm{Q} / \mathrm{v}=$ & 1.04 & 1 & - \\
\hline Velocity through the bar screen, $\mathrm{m} / \mathrm{s}$ & $\mathrm{V}_{\text {thru }}$ & & 0.48 & $\leq 0.9$ \\
\hline Approach velocity, m/s & $\mathrm{V}_{\mathrm{a}}$ & & 0.6 & $\geq 0.4$ \\
\hline
\end{tabular}

Here, velocity $=v=1 / n * R^{2 / 3} * S^{0.5}$ and $Q=v A$

In particular, energy savings must be taken care of aeration, pumping, heating and mixing. In municipal WW treatment, biological treatment generally requires high-energy consumption in the range of $50-60 \%$ of plant usage (8). Thus, energy consumption is one of the major expenses in operating a WW treatment plant. Changes in biological treatment processes by introducing different green technology can significantly reduce the energy demand at a treatment plant. Chemicals such as inorganic salts for phosphorus precipitation or sources for denitrification efficiency and the costs associated with the collection and disposal of sludge (22) must be considered while designing the plants. Activated sludge treatment has many challenges. For examples, activated sludge plants are very expensive to construct and occupy substantial land areas as well as require large footprint as per demands. Moreover, sludge is the residue generated during physical, chemical and biological treatment. The disposal of excess sludge generated from plant operation is one of the environmental challenges for wastewater treatment. The recycling of sludge (containing useful organic matter and nutrients in agriculture) is considered as one of the best solutions. Project items such as machines, man power (salaries), purchases, WWTP construction, administration costs, energy and maintenance costs, installation and construction costs to be evaluated for the optimum cost prediction are the major challenges in WW industry. Adequately trained and certified individuals must maintain and operate wastewater treatment facilities. To recruit skilled operator is one of the challenges in WW industry. The appropriate construction materials selection under prevailing conditions of exposure to hydrogen sulphide and other corrosive gases, greases, oil and other constituents frequently present in WW is one of the challenges for design engineer. The appropriate selection of metals and paints can reduce galvanic action. The water pumping, storage, piping, valves, metering and splash guards' materials should be specially selected on the basis of the physical and chemical characteristics and their interaction to each corrosive chemical. For WWTP, several additional factors must be considered after solving all technical or mechanical facilities. First, the challenges from the plant adaptation should be resolved for different types of perturbations. Very few WWTPs receive a continuous or constant influent either in quantity or quality, but are subject to daily, weekly and annual variations (23, 24). Secondly, the plant instrumentation, control and automation are always required to operate the system properly. It is important to measure the performance of the controller and the degree of adaptability to different perturbations under certain operating conditions (25). Thus, the selected alternative must follow the operating variables within an operating space defined by a set of constraints, which may be process (biomass, oxygen requirements), equipment (maximum pumping rates) or safety (effluent requirements) related. According to Hreiz et al. (2015), WWTPs are facing an important challenge while trying to achieve optimum design and operation due to the set-regulatory standards. The designer should also consider adequate safety measure to satisfy the particular needs for plant personnel, neighborhood or visitors from hazards. It increases the construction and operation cost.

\section{Conclusions}

To fulfill the water demand in any city is one of the most challenging tasks. Treated WW could be used as alterative options for agricultural, gardening, cleaning, industrial manufacturing, as well as other household purposes. It can reduce 
the pressures on other water sources in any region where surface or groundwater is not sufficiently available. Moreover, some WWTPs can operate for the production of biofuel or electricity source (i.e. act as a resource recovery option). To achieve the goal of best WW treatment, environmental, social, and economical costs should be considered as factors determining process selection in light of emerging issues of sustainability. Those factors can vary with various technological applications during system design. Environmental issues or social issues should be evaluated properly prior to the approval of plant design. Social issues sometimes consider the opportunity cost of spending money on water treatment as opposed to other community services.

The present manuscript discussed briefly the plant location, effluent quality requirements, design issues, environmental impacts, details, and safety concerns. It also highlighted the necessary flexibility to operate the treatment satisfactorily within the expected range of influent WW characteristics and flows. The appropriate design of the various process units of WWTPs would be based upon the hydraulic, organic and inorganic loading rates. All units of WWTPs should be hydraulically capable of handling the expected condition. All piping and channels must be designed to carry out the design peak instantaneous flows and it can be fully or partially equalized. Sampling equipment should be installed at all mechanical plants and it could also be facilitated as needed for influent sampling and for monitoring of plant performance.

In conclusion, the designer should accommodate the safety facilities while constructing the plants or performing the plant operation. The protective equipment (e.g. self-contained breathing apparatus, protective clothing, gas detection equipment, goggles, gloves, hard hats, steel-toe safety boot and safety harnesses) are always be available for employees. Moreover, the appropriately placed warning signs, adequate ventilation, all health and safety issues must be included to ensure safe operation at the construction site.

\section{Ethical issue}

Authors are aware of, and comply with, best practice in publication ethics specifically with regard to authorship (avoidance of guest authorship), dual submission, manipulation of figures, competing interests and compliance with policies on research ethics. Authors adhere to publication requirements that submitted work is original and has not been published elsewhere in any language.

\section{Competing interests}

The authors declare that there is no conflict of interest that would prejudice the impartiality of this scientific work.

\section{Authors' contribution}

All authors of this study have a complete contribution for data collection, data analyses and manuscript writing.

\section{References}

1. Tchobanoglous G, and Burton FL, Stensel, HD. Wastewater Engineering. Treatment Disposal Reuse ( $5^{\text {th }}$ Eds.). 2003: Metcalf and Eddy Inc. McGraw-Hill Education ISBN.

2. $\mathrm{Hu} \mathrm{Z}$, Houweling D, and Dold P. Biological Nutrient Removal in Municipal Wastewater Treatment: New Directions in Sustainability. Journal of Environmental Engineering, 2012; 138 (3): 307-317.
3. Hreiz R, Latifi MA, and Roche N. Optimal design and operation of activated sludge processes: State-of-the-art. Chemical Engineering Journal, 2015; 281: 900-920.

4. Wakelin SA, Matt J. Colloff MJ, and Kookana1 RS. Effect of Wastewater Treatment Plant Effluent on Microbial Function and Community Structure in the Sediment of a Freshwater Stream with Variable Seasonal Flow. Applied and Environmental Microbiology. 2008; 74(9): 2659-68.

5. Hasan HA, Muhammad MH, Ismail NI. A review of biological drinking water treatment technologies for contaminants removal from polluted water resources. Journal of Water Process Engineering 2020; 33: 101035.

6. Antalová V, Slučiaková S, Haluš M. Estimating environmental benefits of wastewater treatment in Slovakia. 2018: Institue of Env Policy, Ministry of Environment of the Slovak Republic.

7. Ouda OKM. Treated wastewater use in Saudi Arabia: challenges and initiatives. International Journal of Water Resources Development. 2016; 32(5): 799-809.

8. Davis ML. Water and wastewater Engineering: Design principles and practice. 2011: McGraw-Hill Education, 2 Penn Plaza, New York, USA. ISBN 978-007-128924-5.

9. Seneviratne M. Wastewater Treatment Technologies. 2014: ZDHC Publisher.

10. Ministry of the Environment. Design Guidelines for Sewage Works. Chapter 8: Design Considerations for Sewage Treatment Plants. Ontario, Canada. 2008: Ontario Ministry of the Environment. ISBN 978-1-4249-8438-1.

11. Royal commission environmental regulations. Volume I: Environmental Control Department. 2004: Kingdom of Saudi Arabia.

12. General Environmental Regulations and Rules for Implementation. 2001: Kingdom of Saudi Arabia Presidency of Meteorology and Environment.

13. Abugdera AF, Faris BM, Abugderha MM. Analytical Study of Environmental Impact Assessment for a Wastewater Treatment Plant in Sabratha Libya. International Journal of Scientific and Engineering Research. 2018; 9(5): 199. ISSN 2229-5518.

14. Abaza H, Bisset R, and Sadler B. Environmental Impact Assessment and Strategic Environmental Assessment: Towards an Integrated Approach. 2004: UNEP. http://www.unep.ch/etb/publications/EnvImpAss/textONUBr.pdf.

15. Azad AS. Design of primary sewage treatment plant. Madras Agricultural Journal 1995; 81(5): 272 - 273.

16. Besnarek W, Tkaczyk P. Waste water treatment and disposal. Agricultural journal. 2001; 50 (72)

17. Singh A. Design of Primary Sewage Treatment Plant. M.Tech Thesis. BIT Mesra Campus, Allahabad, India. 2011: https://www.academia.edu/6078256/design_of_primary_sewage_tre atment_plant

18. Qasim, SR. Wastewater Treatment Plants: Planning, Design, and Operation. 1998: CRC Press. ISBN 9781566766883.

19. Teklehaimanot GZ, Kamika I, Coetzee, M A A, Momba MNB. Population Growth and Its Impact on the Design Capacity and Performance of the Wastewater Treatment Plants in Sedibeng and Soshanguve, South Africa. Environmental Management. 2015: DOI 10.1007/s00267-015-0564-3.

20. Alsina XF. Conceptual design of wastewater treatment plants using multiple objectives. PhD Thesis. 2008: Department of Physics and Environmental Technology, University of Girona.

21. Copp J. The cost simulation benchmark. Description and Simulator Manual. 2002:Office for Official Publications of the European Communities, Luxembourg.

22. Vanrolleghem PA, and Gillot S. Robustness and economic measures as control benchmark criteria. Water Science and Technology, 2002 45 (4-5): 117-126.

23. Gernaey KV, Van Loosdrecht MCM, Henze M, Lind M, and Jørgensen, SB. Activated sludge wastewater treatment plant modelling and simulation: State of the art. Environmental Modelling 
and Software, 2004; 19(9): 763-783.

24. Isaa HM. Optimization of Wastewater Treatment Plant Design using Process Dynamic Simulation: A Case Study from Kurdistan, Iraq. The Scientific Journal of Koya University. 2019; Article ID: ARO.10488: $\quad 6 \quad$ DOI: $\quad 10.14500 /$ aro. 10488 . 25. Olsson G, and Newell B. Wastewater Treatment Systemsmodelling, diagnosis, control. 1999: IWA. ISBN13: 9781900222150. 